\title{
Changes in Biometric, Density, and Microscopic Features of Parrotia persica Trees in Longitudinal and Radial Directions of the Stem
}

\begin{abstract}
Ali Hassanpoor Tichi, ${ }^{\mathrm{a}, *}$ Hadi Gholamiyan, ${ }^{\mathrm{b}}$ and Mojtaba Rezanezhad Divkolae ${ }^{\mathrm{a}}$
The biometric, density, and microscopic features of Parrotia persica species were investigated in this work. Three completely healthy $P$. persica trees were randomly felled. Three discs of $5 \mathrm{~cm}$ thickness were cut at three height levels (at breast height, $3 \mathrm{~m}$, and $4.5 \mathrm{~m}$ ) of each stem. The test specimens were sequentially taken from pith to bark. The biometric characteristics of the fiber and their density were analyzed. The microscopic features were studied according to the IAWA List of Hardwoods. It was found that all biometric factors of $P$. persica were decreased with increasing tree height from base to top. In contrast, these factors were also increased with the increase of distance from the pith toward the bark. Oven-dry density and basic density were decreased with an increase in the height along the tree stem. However, in the transverse direction, oven-dry density and basic density were increased from pith to bark. The anatomical study indicated that $P$. persica is a diffuse-porous hardwood that has distinct growth ring boundaries, heterogeneous rays, scalariform perforation, and alternative intervessel pits.
\end{abstract}

Keywords: Parrotia persica; Diffuse-porous hardwood; Basic density; Alternative pits

Contact information: a: Department of Wood Science and Engineering, Technical Faculty of No. 2, Mazandaran Branch, Technical and Vocational University (TVU), Sari, Iran; b: Assistant Professor, Department of Wood and Paper Science \& Technology, Faculty of Natural Resources, University of Tehran, Karaj, Iran; *Corresponding author: hasanpoortichi@gmail.com

\section{INTRODUCTION}

Due to the extensive use of wood-based products worldwide, the importance of this material has increased. Because of the lack of awareness about the wood utilization, its applications, and the correct way of use, a massive volume of wood is wasted. However, with the remarkable development of technology in all fields, the efficient uses of wood have multiplied. At a fundamental level, the principal and practical uses of various wood species have an undeniable relationship with its basic features, and given that the wood is a biological material, these features (including physical, anatomical, and biometric properties) undergo noteworthy changes at different parts of trees. These variations in wood properties must always be considered to improve the end-use of wood. Because wood is one of the few renewable resources on the earth and is an important raw material for the wood and paper industry, if sufficient care and attention are not paid to its harvesting, its workability and usability will be affected. Therefore, the investigation of the fundamental features (such as biometric, physical, and anatomical features) of different wood species have been considered by the wood and paper industry researchers. In this context, there has been a need for an extensive study on Parrotia persica wood. 
The Persian ironwood tree (Parrotia persica) is a member of the Saxifragales order, Hamamelidaceae family, and from the Parrotia genus. The P. persica is a hardwood tree that is native to the northern forest of Iran. The best growth condition of P. persica is in slightly acidic, medium moisture, well-drained soils, and exposure to full sun. However, $P$. persica can tolerate highly acidic to neutral soil $\mathrm{pH}$, dry soil, and partial shade. $P$. persica is a small to medium in size and single trunk tree that eventually grows to $6 \mathrm{~m}$ to $12 \mathrm{~m}$ tall (but generally grows to $3 \mathrm{~m}$ after 7 to 8 years) or a large, multi-stemmed shrub with a spreading of irregular branching pattern that grows to $4.5 \mathrm{~m}$ tall. The trunk wood is light gray in color. In winter, exfoliating bark peels away and creates a camouflage of pinks, grey-greens, and browns, while twigs hold black, velvety buds. This is especially decorative in more mature trees. Apetalous flowers with dense, red stamens surrounded by brownish bracts appear in late winter to early spring before the foliage. Oval to oblong leaves emerge reddish-purple in spring, mature to a lustrous, medium to dark green in summer, and change to variable shades of yellow, orange, and red in fall.

Parsapajouh and Schweingruber (2001) investigated the anatomical features of $P$. persica. They concluded that $P$. persica is a diffuse-porous hardwood with homogeneous wood. The vessel is exclusively solitary ( $90 \%$ or more) and is small in size. The vessels are widely distributed in each growth ring. Rays are 10 to 14 per $\mathrm{mm}^{2}$, both uniseriate and biseriate. The growth ring boundaries are distinct due to the 2 to 3 denser fiber cells and sometimes are seen as discontinuous. The parenchyma cells are abundant and diffuse. Further, $P$. persica has uniseriate and biseriate heterogeneous ray cells, but the biseriate cells are more common. Their maximum height is up to 12 cells, and sometimes two ray cells are connected in the longitudinal direction. Additionally, long and abundant vessels are seen. The vessel perforation is scalariform, which usually has 8 bars. The pits between vessels are alternate pitting, and the vessel-ray pitting is common in rounded or oval shapes ( 3 to 4 per cell). The ground tissue is composed of long and abundant fiber tracheid and the heterogeneous ray cells are procumbent with mostly 2 to 4 rows of square marginal cells.

The fiber length and juvenile and mature wood zones from Hevea brasiliensis trees grown in Brazil were determined by Ferreira et al. (2011). They showed that the average values of fiber length for juvenile wood are significantly shorter than the mature wood. The average value of fiber length for juvenile wood was $1.26 \mathrm{~mm}$ and that for mature wood was $1.51 \mathrm{~mm}$.

Juvenile and mature wood properties of naturally-grown fir trees were studied by Passialis and Kiriazakos (2004). They concluded that the tracheid length in radial direction was increased from pith to bark.

Hassanpoor Tichi and Rezanezhad Divkoiae (2020) examined the changes in physical, anatomical, and biometric characteristics of Morus alba in the longitudinal and transverse axis of the stem. The results indicated that all the biometric ratios of Morus alba in radial direction were significantly increased from the pith to toward bark. The results also revealed that the physical properties of Morus alba including oven-dry and basic density were increased from pith to bark. In the longitudinal axis, at three height levels along the stem within each disc, all biometric and physical properties were regularly decreased with increasing height from base to upward. Therefore, the purpose of this study was to determine and report changes in anatomical, density and biometrical features of $P$. persica wood in longitudinal and transverse directions as well as investigation Fiber morphology and wood density for use in wood industry (plywood and cellulose). 


\section{EXPERIMENTAL}

\section{Materials}

To determine the density, anatomical, and biometric properties of P. persica, three completely healthy trees (equal diameter and age) were randomly selected and cut from the Babol region, Mazandaran province, Iran in geographical coordinates $36^{\circ} 34^{\prime} 15^{\prime \prime} \mathrm{N}$ and $52^{\circ} 44^{\prime} 20^{\prime \prime} \mathrm{E}$ at an altitude range of $2 \mathrm{~m}$ to $50 \mathrm{~m}$ above sea level, taking into account the absence of any fungal decays, insect damages, mechanical damages, checks, and splits. The $P$. persica tree height was $6.5 \mathrm{~m}$ tall, 40 years old, and $52 \mathrm{~cm}$ in diameter at breast height. Then from the at breast height, height 3 meters and height 4.5 meters disc with a thickness of $5 \mathrm{~cm}$ was prepared. Medium annual ring width at breast height, height 3 meters and height 4.5 meters were $6 \mathrm{~mm}, 4.8 \mathrm{~mm}$ and $3.3 \mathrm{~mm}$, respectively. Next, each disc was sequentially cut into $2 \mathrm{~cm} \times 2 \mathrm{~cm}, 3$-cm-long specimens from the pith towards the tree bark (Fig. 1). After that, the test samples were transported to the wood and paper industries unit laboratory of Shahid Hasheminejad Technical University (at $20^{\circ} \mathrm{C}$ temperature and relative humidity of $65 \%$ ) in Sari for the examination of density, anatomical, and biometric properties of $P$. persica.

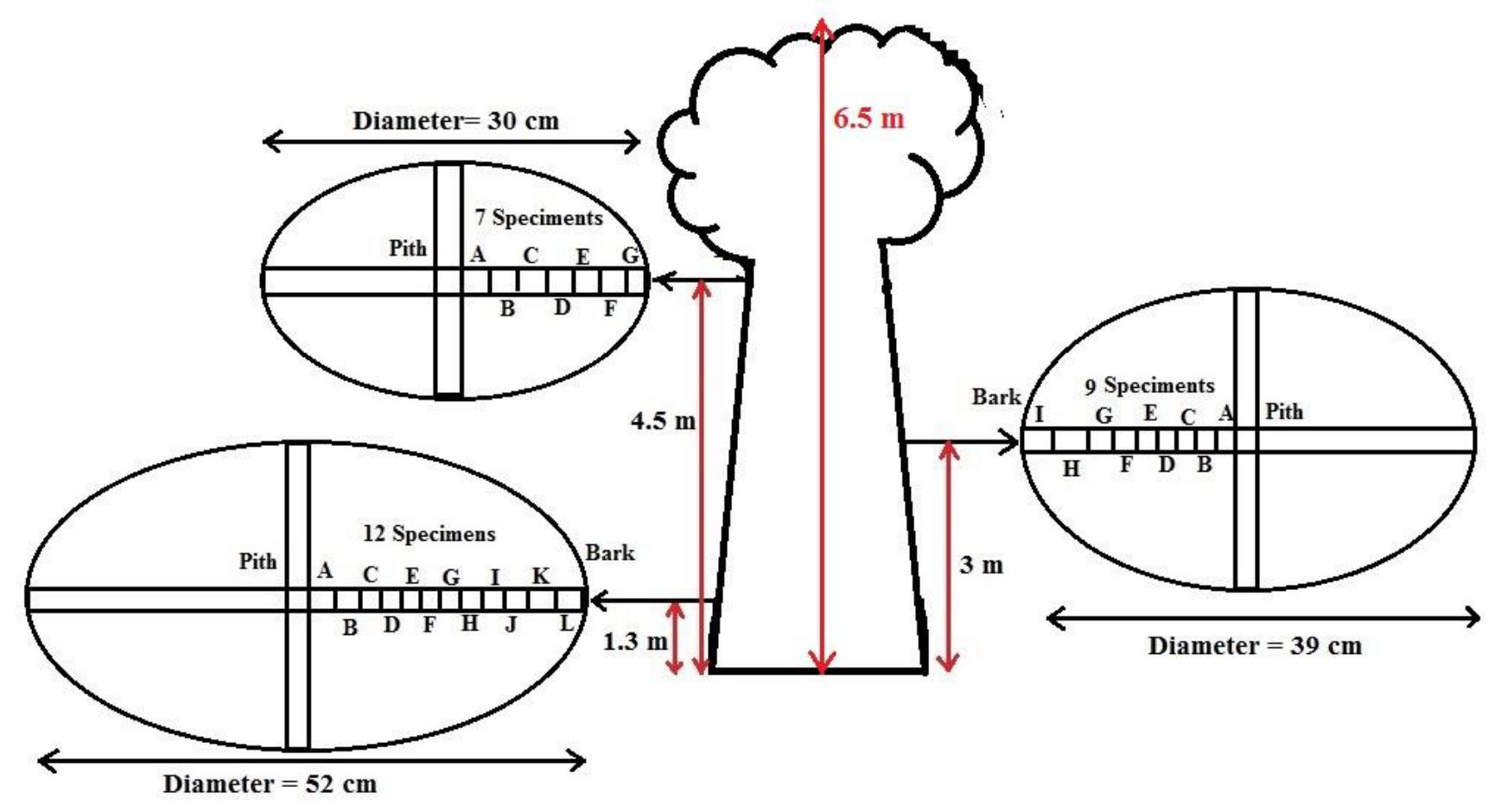

Fig. 1. Patterns of cut and numbers of test specimens at three heights level

\section{Methods}

Preparation of microscopic sections

The anatomical features of $P$. persica were studied based on the IAWA hardwood list. Samples from near the bark and pith wood with dimensions of $2 \mathrm{~cm} \times 2 \mathrm{~cm} \times 3 \mathrm{~cm}-$ long were prepared (Wheeler et al. 1989). Due to the hardness of the tissue, the samples were immersed in a mixture of $96 \%$ alcohol, water, and glycerin in volume proportions of 1:1:3. Then, microscopic sections were obtained using a microtome (ROTO-CUT 100 
Advance, Scilab, Bransley, England) equipped with a knife angle of approximately $15^{\circ}$ for hardwood tissue. Subsequently, to remove the cellular content, the micro-sections were immersed in javel water (sodium hypochlorite solution) for 15 to $30 \mathrm{~min}$. After that, the sections were rinsed with water 2 to 3 times until the odor of javel water disappeared. Then, the sections were painted with a dual solution of safranin $0.04 \%$ and Astra-blue $0.15 \%$ (water soluble) for 3 to $5 \mathrm{~min}$. To remove the excess stains, the sections were rinsed once with water, once with $50 \%$ alcohol, 2 to 3 times with $96 \%$ alcohol, and once with $100 \%$ alcohol. Samples were washed and placed in xylene solution. Finally, each section was mounted on a slide. To analyze the microscopic features near the bark and pith wood of $P$. persica, a light microscope equipped with a graduated eyepiece was used (Parsapajouh and Schweingruber 2001).

\section{Preparation of Samples for Biometric Examination}

Biometric features of $P$. persica fibers were measured using Franklin's method (Franklin 1945). For this purpose, matchsticks of fibers were obtained from longitudinal cuts of the $2 \mathrm{~cm} \times 2 \mathrm{~cm} \times 3 \mathrm{~cm}$ - long specimens with radial and tangential dimensions of $2 \times 2 \mathrm{~mm}^{2}$, respectively. Then, the matchsticks were put into tubes that contained a 1:1 (v/v) mixture of acetic acid and hydrogen peroxide. Each test tube was coded subsequently. To macerate the matchsticks, test tubes were kept in the oven for $48 \mathrm{~h}$ at $70{ }^{\circ} \mathrm{C}$. Next, white specimens were bleached inside the test tube; they were washed with distilled water 5 to 6 times, washed, and stained with safranin. To examine biometric ratios of $P$. persica fibers, at least 30 completely intact fibers were used on each slide and scanned by a light microscope (CX22; Olympus, Tokyo, Japan). Fiber length was measured using 10x magnification of objective lens. The fiber wall thickness, lumen diameter, and fiber diameter were measured using 100x magnification of objective lens.

\section{Preparation of Samples for Measuring Density}

To examine the density of $P$. persica fibers including oven-dry density and basic density, test specimens of $2 \mathrm{~cm} \times 2 \mathrm{~cm} \times 3 \mathrm{~cm}$ - long were prepared according to the ISO 13061-2 (2014) standard. To measure the changes in density from pith to bark, a crosssampling technique was used. The orthotropic and geometrical axes in specimens were completely matched. Then, samples were coded and soaked in water for a week to saturate them with water. After that, the green weight of samples was measured using a digital scale with an accuracy of $0.001 \mathrm{~g}$. The dimensions of samples after saturation were measured in the longitudinal, radial, and tangential directions by a digital caliper (EK610i; AND, Tokyo, Japan) with $0.01 \mathrm{~mm}$ accuracy. Next, the samples were kept in the oven at a temperature of $103 \pm 2{ }^{\circ} \mathrm{C}$ for $24 \mathrm{~h}$. Then, the oven-dry weight and dimensions of samples were measured. Finally, oven-dry density and basic density were calculated by dividing the dry weight by dry volume and the dry weight by green volume, respectively.

\section{Statistical Analyses}

Statistical analyses were performed using Statistica software (version 13, Dell Inc., Round Rock, TX, USA) at a significance level of $\alpha=0.05$. The obtained results were analyzed statistically, and an analysis of variance (ANOVA) was performed to determine the significance of the tested parameters. A Duncan's multiple range test (DMRT) was performed to compare the treatment means. 


\section{RESULTS AND DISCUSSION}

\section{Biometric Properties}

As shown in Fig. 2, the independent and interaction effects of longitudinal and transverse axes on fiber length, fiber diameter, fiber lumen diameter, and fiber wall thickness were significant at the $95 \%$ and $99 \%$ levels, respectively. With increasing tree height along the stem from base to top, the average value of fiber length was decreased. The highest value of fiber length at breast height level in sample L (near the bark) was 1.85 $\mathrm{mm}$, and the lowest value of fiber length was at $4.5 \mathrm{~m}$ height in sample A (near the pith) was $1.19 \mathrm{~mm}$. Fiber length was increased from the pith (sample A) to bark (sample L) at three height levels of the tree stem (Fig. 2A). The trend of changes in fiber lumen diameter followed a decreasing pattern with increasing the height from the stump reaching the higher zone of tree stem (near the crown). In general, the maximum value of fiber lumen diameter was found at breast height. In sample L (near the bark) the value was $8.66 \mu \mathrm{m}$, and the lowest value of fiber lumen diameter at $4.5 \mathrm{~m}$ height in sample A (near the pith) was at $6.36 \mu \mathrm{m}$. Changes in fiber lumen diameter at three height levels had an increasing trend from the pith to bark (Fig. 2B). With increasing the tree height from breast height to crown, the fiber diameter followed a decreasing pattern. The maximum value of fiber diameter at the stump in the bark area (sample L) was $25.63 \mu \mathrm{m}$, and the minimum value of fiber diameter was at $4.5 \mathrm{~m}$ height in the pith area (sample A) was $20.89 \mu \mathrm{m}$. The fiber diameter in P. persica increased from pith to bark at three height levels (Fig. 2C). As the tree height increased, fiber wall thickness decreased. The highest value of fiber wall thickness at breast height in sample L (near the bark) was $16.97 \mu \mathrm{m}$, and the lowest value of fiber wall thickness at $4.5 \mathrm{~m}$ was $14.53 \mu \mathrm{m}$. Thus, the average value of fiber wall thickness increased from pith to bark at three height levels (Fig. 2D).

The increase in fiber dimension, including fiber length, fiber diameter, and fiber wall thickness from the pith to bark, can be explained by the increase in the age of initial cambial cells that a linear relationship exists between fiber length and cambium age. With increasing age of the tree, the fiber length also increased (Zobel and van Buijtenen 1989; Zobel and Sprague 1998; Hassanpoor Tichi and Rezanezhad Divkolae 2020). Wood cells in a growth ring are the result of the annual activity of the cambial cells. In fact, wood cells are made by cambial cell division, and these cells become more mature with the increase in the age of the tree. Consequently, the cells that they produce become longer and thicker. Thus, the main reason for the higher value of fiber dimension in the bark zone compared to that in pith zone can be due to the activity of mother cambium cells in juvenile wood and mature wood zone (Adamopoulos and Voulgaridis 2002; Marsoem et al. 2002).

All biometric factors including fiber length, fiber diameter, and fiber wall thickness were decreased with increasing tree height along the stem from the base (breast height) to top (crown). These changes in biometric factors in the longitudinal axis can be explained by the presence of juvenile wood in the upper zone of the tree and mature wood in the lowest zone of the tree, which has differences in cell structures (Zobel and Sprague 1998; Hasanpoor Tichi and Rezanezhad Divkolae 2020).

Therefore, biometric properties are one of the most important factors for the wood and paper industry's mill and play an important role in the product yields of these mills. For instance, fiber length is a vital factor for pulp and paper mills, because, as fiber length increases the quality of produced paper increased due to the higher value of fiber ratios such as rankle ratio, slenderness ratio, and flexibility ratio. Hence, these biometric factors and their changes in various parts of the trees is important for pulp and paper mills. 


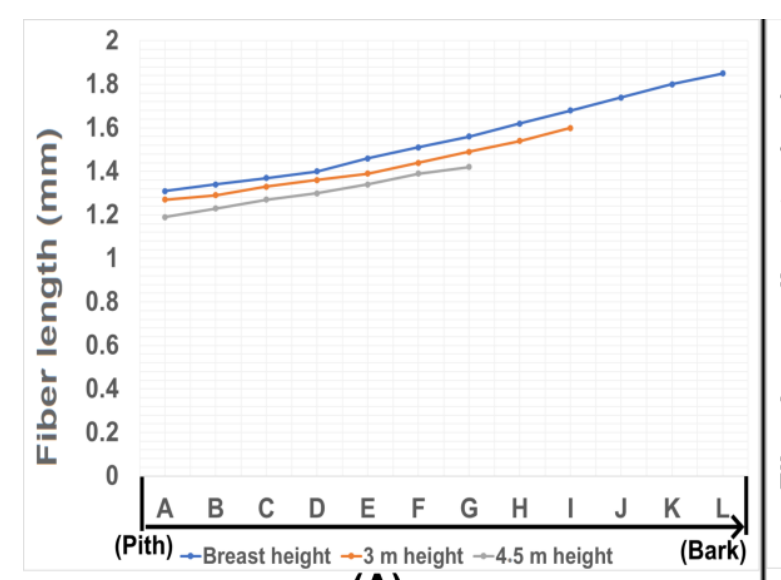

(A)

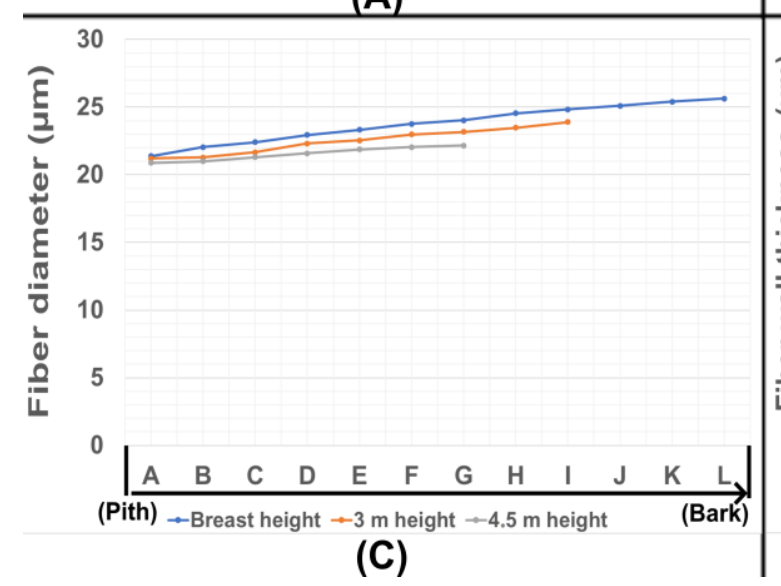

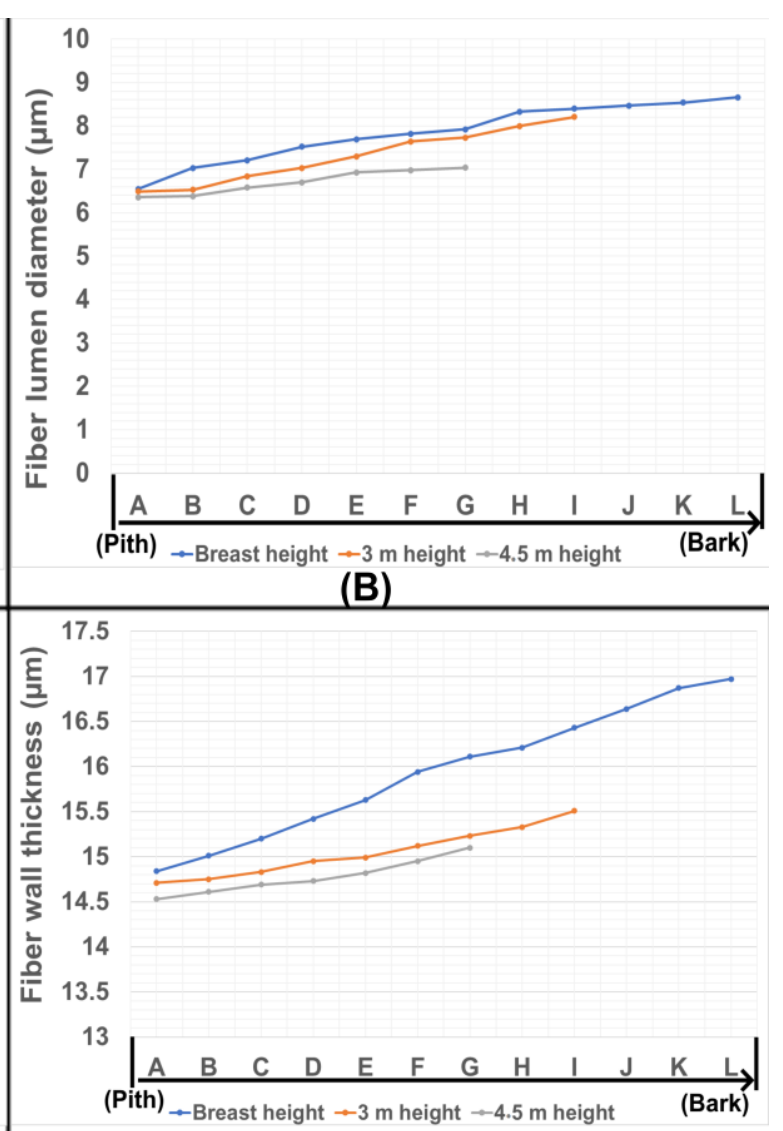

(D)

Fig. 2. Changes in (A) fiber length, (B) fiber lumen diameter, (C) fiber diameter, and (D) fiber wall thickness of $P$. persica trees in various parts of the stem

\section{Density}

As shown in Fig. 3, the independent and interaction effects of longitudinal and transverse axes on oven-dry density and basic density were significant at the $95 \%$ levels. As tree height from breast height to crown increased, the trend of oven-dry density and basic density changes followed a decreasing pattern. The greatest oven-dry density and basic density at breast height in the bark area (sample L) were $0.83 \mathrm{~g} / \mathrm{cm}^{3}$ and $0.67 \mathrm{~g} / \mathrm{cm}^{3}$, respectively. The lowest oven-dry density and basic density were observed in the area of the crown near the pith (sample A): $0.5 \mathrm{~g} / \mathrm{cm}^{3}$ and $0.42 \mathrm{~g} / \mathrm{cm}^{3}$, respectively (Fig. 3). As shown in Fig. 3, the density increased from the pith to the bark.

The higher value of density (basic and oven-dry density) in the bark zone compared to those in the pith zone confirmed the accuracy of biometric results. Regarding the higher value of mature wood in the bark area compared to that in the pith area and the differences in the cell structure between these two areas, especially higher fiber wall thickness in mature wood, which is the main reason for the increase in density, it is concluded that the bark zone was denser than the pith zone. Moreover, the oven-dry density and basic density decreased in longitudinal axes by increasing the height along the stem, from the base to the top. These results can be explained by the higher value of the juvenile wood in the upper zone of the tree stem (Hasanpor Tichi and Rezanezhad Divkolae 2020). 
The density is one of the most important features of wood that both wood and paper industries have to focus on. For instance, density has a correlation with strengths in wood that is important for construction. The compression ratio correlates with wood density. In particleboard, Oriented Strand Board (OSB), Parallel-Strand Lumber (PSL), Laminated Strand Lumber (LSL), and Oriented Strand Lumber (OSL) production, the increase in compression ratio to a certain extent, increases the board strength. The higher compression ratio is obtained with the lower value of density. Hence, these features in a tree stem and their changes in different parts of the tree are vital for all wood and paper industry's mills.

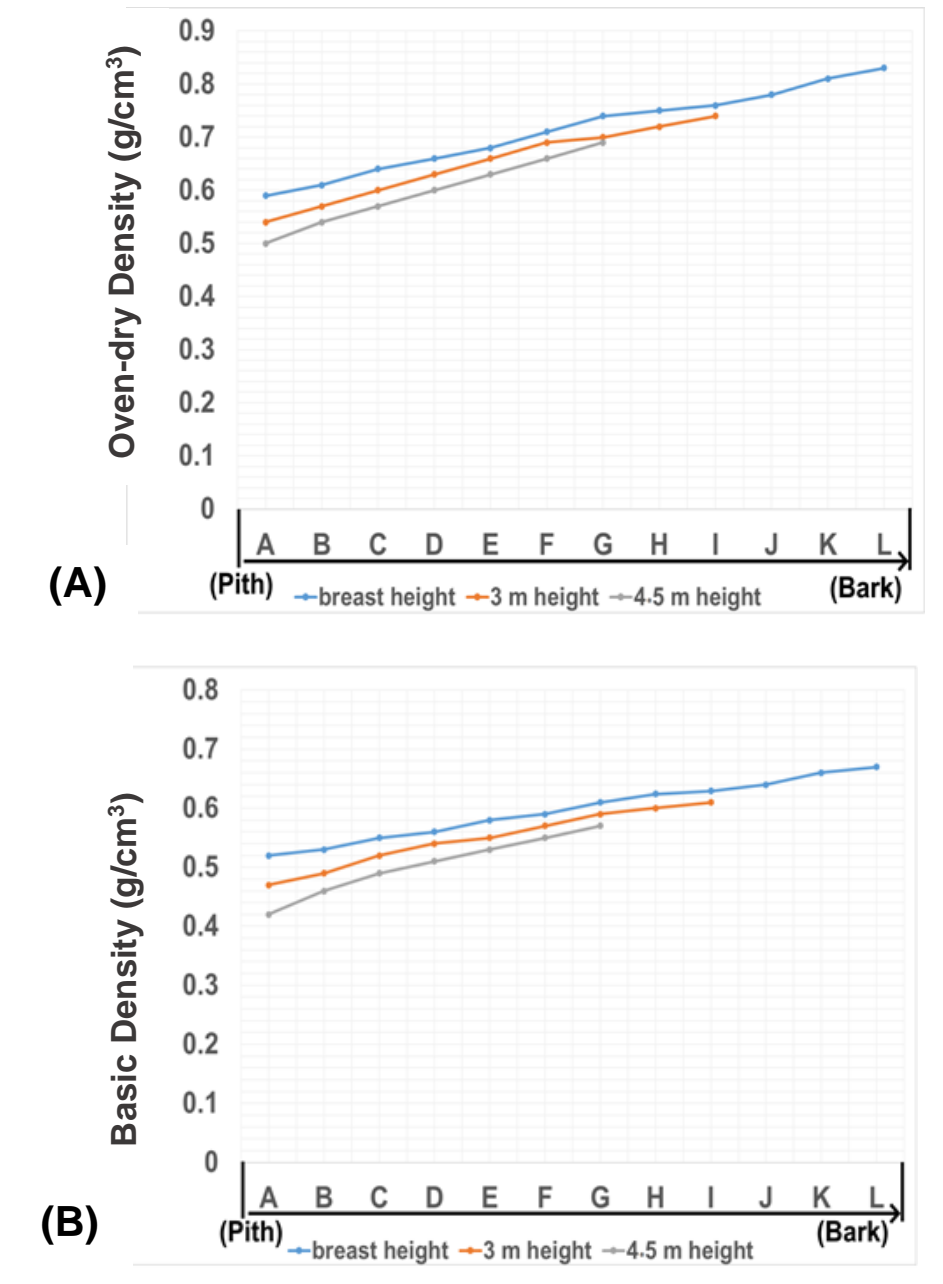

Fig. 3. Changes in (A) oven-dry density and (B) basic density of $P$. persica trees in different parts of the stem

\section{Microscopic Features}

To accurately study the anatomical features of $P$. persica, the most important features near the bark (sample L) and near the pith (sample A) wood were studied following the IAWA hardwood list (Table 1). The results showed that most microscopic features of near the bark (sample L) and near the pith (sample A) wood of P. persica are in common that the most important of them are diffuse-porous wood, with distinct growth ring boundaries, scalariform perforation, alternative inter vessel pits, vessel-ray pits with distinct borders similar to intervessel pits in size and shape throughout the ray cell, Apotracheal parenchyma diffuse, and presence of prismatic crystals in ray cells and axial 
parenchyma. Nevertheless, there were some differences between these two zones of wood, which are highlighted in yellow in Table 1 . The most important features of them are the larger tangential diameter of vessel lumen near the bark area than near the pith area, more vessels per millimeter in near the bark area than near the pith area, longer ray (maximum height: 27 cells) near the bark area compared to that near the pith area (maximum height: 15 cells), and wider ray cells near the bark area than near the pith area.

Table 1. Microscopic Features Near the Pith and Bark of P. persica Wood According to IAWA Hardwood List

\begin{tabular}{|c|c|c|c|c|}
\hline Feature & $\begin{array}{l}\text { Number } \\
\text { of } \\
\text { Features }\end{array}$ & $\begin{array}{l}\text { Description } \\
\text { (Mature Wood) }\end{array}$ & $\begin{array}{l}\text { Number } \\
\text { of } \\
\text { Features }\end{array}$ & $\begin{array}{c}\text { Description } \\
\text { (Juvenile Wood) }\end{array}$ \\
\hline Growth Ring & 1 & Growth ring boundaries distinct & 1 & Growth ring boundaries distinct \\
\hline Porosity & 5 & Wood diffuse-porous & 5 & Wood diffuse-porous \\
\hline Vessel Arrangement & 8 & Vessels in dendritic pattern & 8 & Vessels in dendritic pattern \\
\hline Vessel Groupings & $\begin{array}{l}9,10 \\
\text { and } 11\end{array}$ & $\begin{array}{c}\text { Vessels partly } \\
\text { solitary, partly in radial multiples } \\
\text { of } 2 \text {, or very small clusters }\end{array}$ & $\begin{array}{l}9,10 \\
\text { and } 11\end{array}$ & $\begin{array}{c}\text { Vessels partly } \\
\text { solitary, partly in radial multiples } \\
\text { of } 2 \text {, or very small clusters }\end{array}$ \\
\hline Perforation Plates & 14 & Scalariform perforation plates & 14 & Scalariform perforation plates \\
\hline \multirow{3}{*}{$\begin{array}{l}\text { Intervessel Pits: } \\
\text { Arrangement and } \\
\text { Size }\end{array}$} & 22 & Alternate intervessel pits & 22 & $\begin{array}{l}\text { Alternate intervessel } \\
\text { Pits }\end{array}$ \\
\hline & 23 & Shape of alternate pits polygonal & 23 & $\begin{array}{c}\text { Shape of alternate pits } \\
\text { polygonal }\end{array}$ \\
\hline & 24 & Size of alternate pits minute & 24 & Size of alternate pits minute \\
\hline Vessel-ray Pitting & 30 & $\begin{array}{c}\text { Vessel-ray pits with distinct } \\
\text { borders; similar to intervessel } \\
\text { pits in size and shape throughout } \\
\text { the ray cell }\end{array}$ & 30 & $\begin{array}{l}\text { Vessel-ray pits with distinct } \\
\text { borders; similar to intervessel } \\
\text { pits in size and shape } \\
\text { throughout the ray cell }\end{array}$ \\
\hline $\begin{array}{l}\text { Tangential Diameter } \\
\text { of Vessel Lumina }\end{array}$ & 41 & $\begin{array}{l}\text { Tangential diameter of vessel } \\
\text { lumina } 50 \text { to } 100 \mu \mathrm{m}(56 \mu \mathrm{m})\end{array}$ & 40 & $\begin{array}{l}\text { Tangential diameter of vessel } \\
\text { lumina } \leq 50 \mu \mathrm{m}(45 \mu \mathrm{m})\end{array}$ \\
\hline $\begin{array}{l}\text { Vessel per Square } \\
\text { Millimeter }\end{array}$ & 48 & $\begin{array}{l}20 \text { to } 40 \text { vessel per square } \\
\text { millimeter (average: } 32 \text { ) }\end{array}$ & 48 & $\begin{array}{l}20 \text { to } 40 \text { vessel per square } \\
\text { millimeter (average: } 21 \text { ) }\end{array}$ \\
\hline $\begin{array}{l}\text { Mean Vessel } \\
\text { Element Length }\end{array}$ & 52 & $\begin{array}{l}\text { Mean vessel element length } \leq \\
350 \mu \mathrm{m}\end{array}$ & 52 & $\begin{array}{l}\text { Mean vessel element length } \leq \\
350 \mu \mathrm{m}\end{array}$ \\
\hline Ground Tissue Fiber & 61 & $\begin{array}{l}\text { Fiber with simple to minutely } \\
\text { bordered pits }\end{array}$ & 61 & $\begin{array}{l}\text { Fiber with simple to minutely } \\
\text { bordered pits }\end{array}$ \\
\hline $\begin{array}{l}\text { Septate Fibers and } \\
\text { Parenchyma-like } \\
\text { Fiber Bands }\end{array}$ & 66 & Non-septate fibers present & 66 & Non-septate fibers present \\
\hline $\begin{array}{l}\text { Fiber Wall } \\
\text { Thickness }\end{array}$ & 70 & Fibers very thick-walled & 70 & Fibers very thick-walled \\
\hline Mean Fiber Length & 73 & Mean fiber length $\geq 1600 \mu \mathrm{m}$ & 72 & $\begin{array}{l}\text { Mean fiber length } 900 \text { to } 1600 \\
\mu \mathrm{m}\end{array}$ \\
\hline $\begin{array}{l}\text { Apotracheal Axial } \\
\text { Parenchyma }\end{array}$ & 76 & Apotracheal parenchyma diffuse & 76 & $\begin{array}{c}\text { Apotracheal parenchyma } \\
\text { diffuse }\end{array}$ \\
\hline $\begin{array}{l}\text { Axial Parenchyma } \\
\text { Cell Type/Strand } \\
\text { Length }\end{array}$ & 90 & Fusiform parenchyma cells & 90 & Fusiform parenchyma cells \\
\hline
\end{tabular}




\section{bioresources.com}

\begin{tabular}{|c|c|c|c|c|}
\hline & 92 & $\begin{array}{c}\text { Four (3 to 4) cells per } \\
\text { parenchyma strands }\end{array}$ & 92 & $\begin{array}{c}\text { Four (3 to 4) cells per } \\
\text { parenchyma strands }\end{array}$ \\
\hline Ray Width & 97 & $\begin{array}{c}\text { Ray width } 1 \text { to } 3 \text { cells (Average: } \\
2 \text { to } 3 \text { cells) }\end{array}$ & 97 & $\begin{array}{c}\text { Ray width } 1 \text { to } 3 \text { cells (Average: } \\
1 \text { to } 2 \text { cells) }\end{array}$ \\
\hline Ray Height & 102 & $\begin{array}{c}\text { Ray height }>1 \mathrm{~mm} \\
\text { (maximum: } 28 \text { cells) }\end{array}$ & 102 & $\begin{array}{c}\text { Ray height }>1 \mathrm{~mm} \\
\text { (maximum: } 15 \text { cells) }\end{array}$ \\
\hline Rays: Cellular & 107 & $\begin{array}{c}\text { Body ray cells procumbent with } \\
\text { mostly } 2 \text { to } 4 \text { rows of } \\
\text { upright/square marginal cells }\end{array}$ & 107 & $\begin{array}{c}\text { Body ray cells procumbent with } \\
\text { mostly } 2 \text { to } 4 \text { rows of } \\
\text { upright/square marginal cells }\end{array}$ \\
\hline Ray Per Millimeter & 115 & $\begin{array}{c}4 \text { to } 12 \text { ray per millimeter } \\
\text { (average: } 10 \text { ) }\end{array}$ & 115 & $\begin{array}{c}4 \text { to } 12 \text { ray per millimeter } \\
\text { (average: } 6 \text { ) }\end{array}$ \\
\hline Prismatic Crystals & 142 & $\begin{array}{c}\text { Prismatic crystals in chambered } \\
\text { axial parenchyma cells }\end{array}$ & 142 & $\begin{array}{c}\text { Prismatic crystals in chambered } \\
\text { axial parenchyma cells }\end{array}$ \\
\hline
\end{tabular}

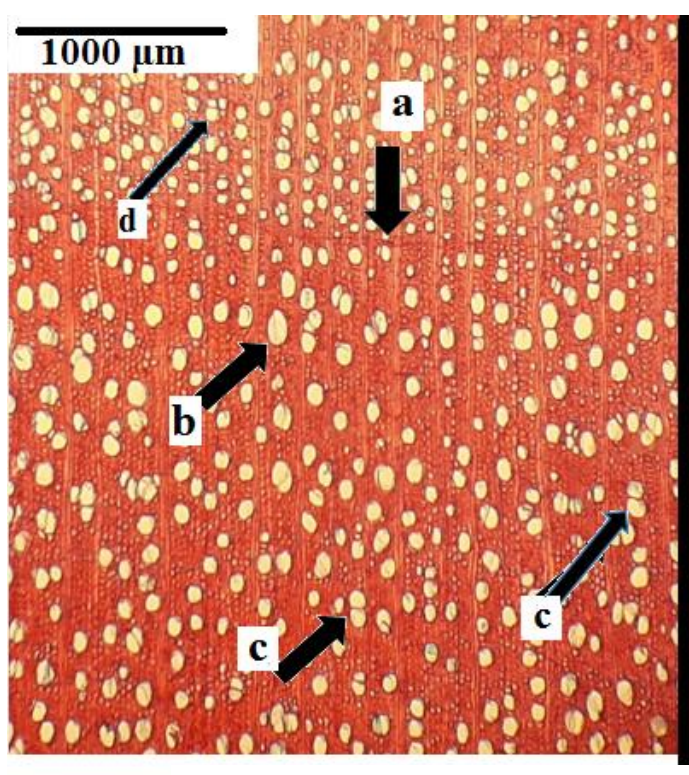

4-A

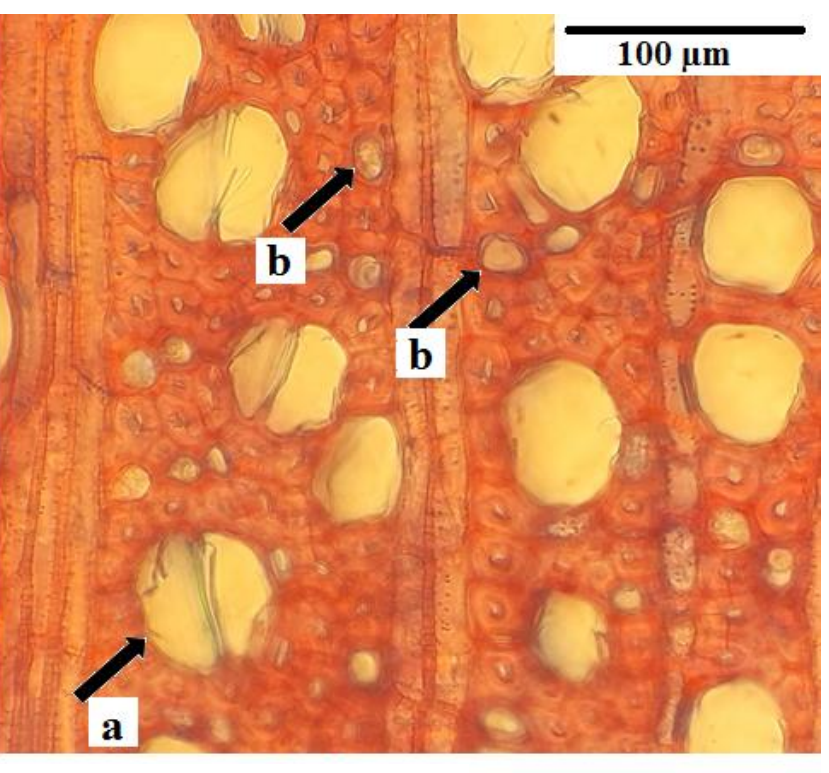

4-B

Fig. 4. Cross-sections of $P$. persica trees (A and $\mathrm{B})$ : 4-A: Distinct growth ring boundary (arrow a), solitary vessel (arrow b), vessels in radial multiples of 2 (arrow c), \& Vessel clusters common (arrow d); 4-B: Vessels in dendritic pattern (arrow a) \& apotracheal parenchyma diffuse (arrow b) 


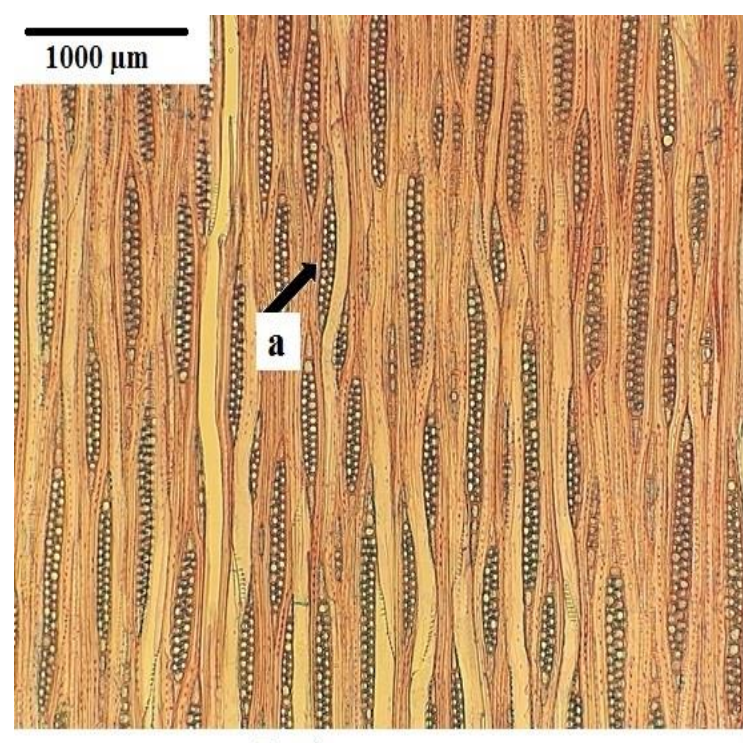

5-A

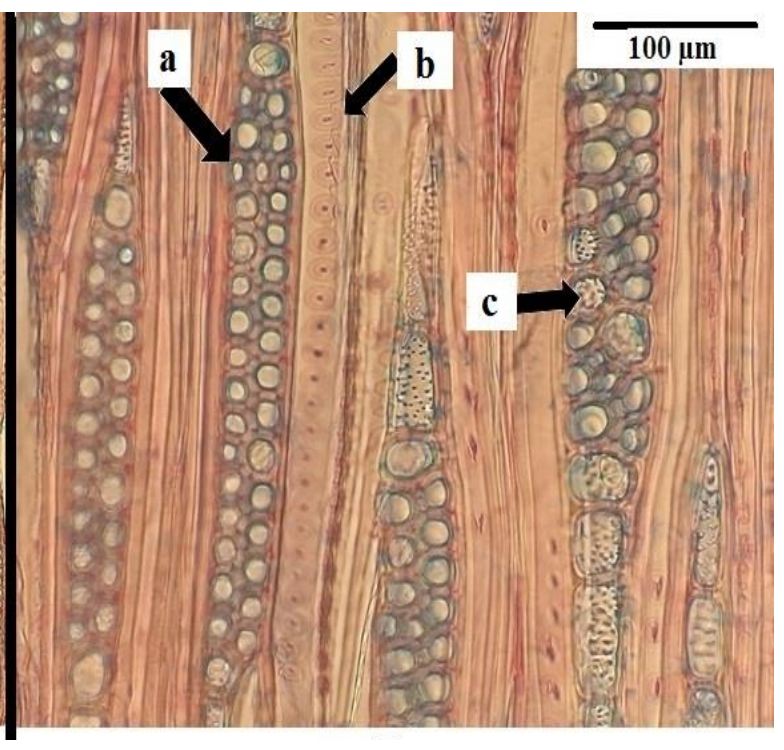

5-B

Fig. 5. Tangential-sections of $P$. persica trees (A and B): 5-A: Ray width 2 cells (arrow A); 5-B: Ray width 3 cells (arrow A), fiber tracheid with bordered pits (arrow B), and prismatic crystals in ray cells (arrow C)

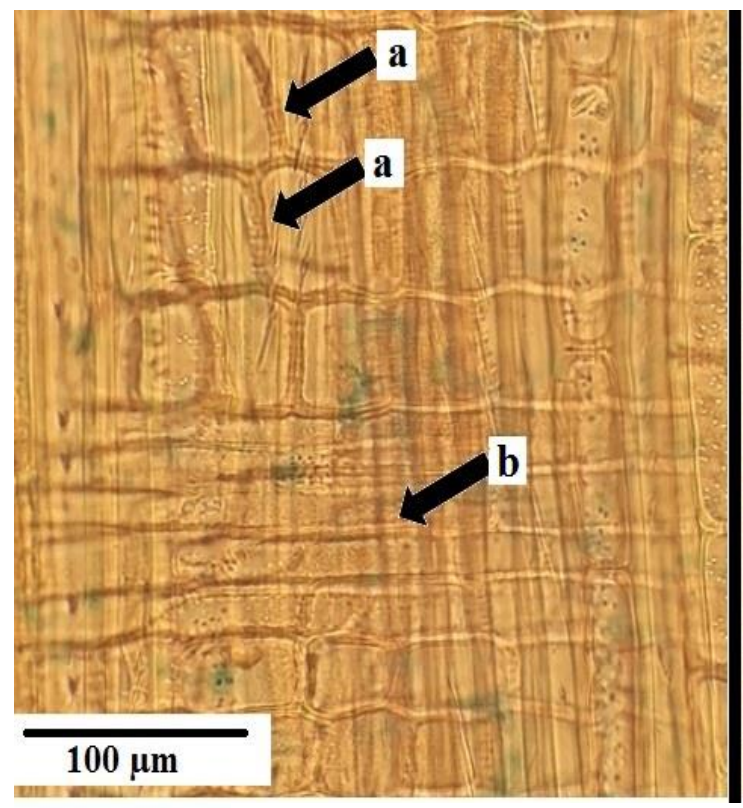

6-A

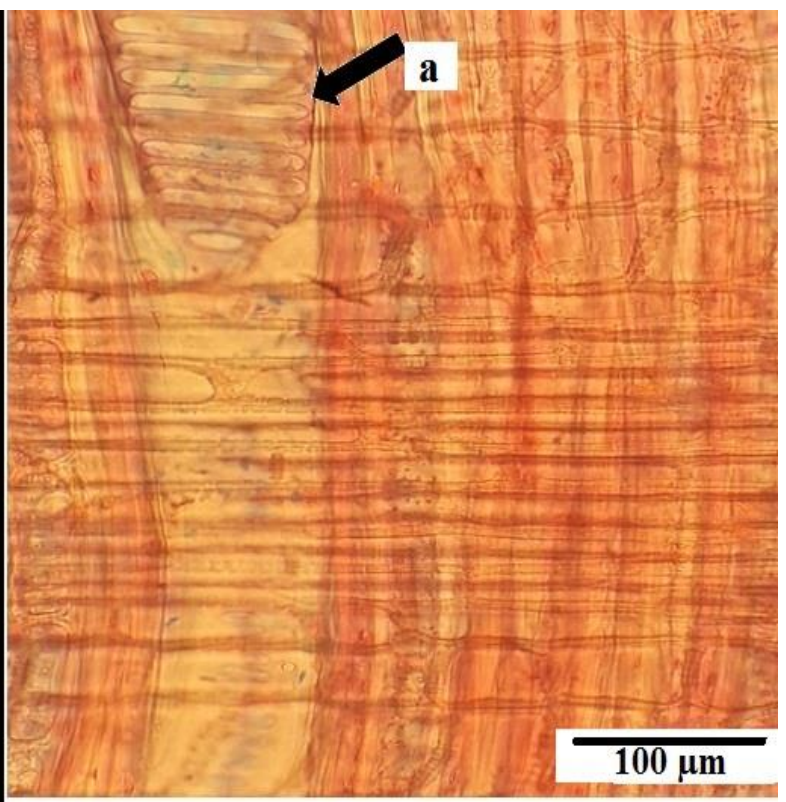

6-B

Fig. 6. Radial-sections of $P$. persica trees (A and B): 6-A: Heterogeneous ray (body ray cells procumbent with mostly 2 to 4 rows of upright/square marginal cells) upright rectangular (arrow $a)$ and procumbent rectangular (arrow b); 6-B: Scalariform perforation (arrow a)

\section{CONCLUSIONS}

1. With increasing the height along tree stem, all biometric factors including fiber length, fiber diameter, fiber wall thickness, and fiber lumen diameter were decreased from base to top. Meanwhile, these factors were increased from pith to bark. 
2. With increasing of the height along the tree stem, oven-dry and basic densities significantly decreased from breast height to near the crown area. In contrast, the average of oven-dry and basic densities was increased from the pith to bark.

3. Anatomical studies of the pith and bark areas of P. persica wood showed that it is a diffuse-porous hardwood, with distinct growth ring boundaries, scalariform perforation, alternative inter vessel pits, and apotracheal parenchyma diffuse.

\section{REFRENCES CITED}

Adamopoulos, S., and Voulgaridis, E. (2002). "Within-tree variation in growth rate and cell dimensions in the wood of black locust (Robinia pseudoacacia)," IAWA Journal 23(2), 191-199. DOI: 10.1163/22941932-90000297

Ferreira, A. L., Severo, E. T. D., and Calonego, F. W. (2011). "Determination of fiber length and juvenile and mature wood zones from Hevea brasiliensis trees grown in Brazil," European Journal of Wood and Wood Products 69, 659-662. DOI: 10.1007/s00107-010-0510-2

Franklin, G. L. (1945). "Preparation of thin sections of synthetic resins and wood-resin composites, and a new macerating method for wood," Nature 155(3924), 51. DOI: $10.1038 / 155051 \mathrm{a} 0$

Hassanpoor Tichi, A., and Rezanezhad Divkolae, M. (2020). "Changes of biometric, physical, and anatomical properties of juvenile wood and mature wood of Morus alba trees in longitudinal and transverse directions," Iranian Journal of Wood and Paper Industries 11(2), 305-316. DOI: http://www.ijwp.ir/article_38023.html

ISO 13061-2 (2014). "Physical and mechanical properties of wood: Test methods for small clear wood specimens. Determination of density for physical and mechanical tests," International Organization for Standardization, Geneva, Switzerland.

Marsoem, S. N., Haryanti, E., and Lukmandaru, G. (2002). "Radial and axial variation in the fibre dimensions and cell proportion of auri (Acacia auriculiformis) wood grown in the community forest," in: The Fifth Pacific Regional Wood Anatomy Conference, Yogyakarta, Indonesia, pp. 9-14.

Parsapajouh, D., and Schweingruber, F. H. (2001). "Different stage of the procedure," in: Atlas of the Woods of North of Iran, Tehran University Publications, Tehran, Iran, pp. 7-8.

Passialis, C., and Kiriazakos, A. (2004). "Juvenile and mature wood properties of naturally-grown fir trees," Holz als Roh-und Werkst 62, 476-478. DOI: 10.1007/s00107-004-0525-7

Wheeler, E. A., Baas, P., and Gasson, P. E. (1989). "IAWA list of microscopic features for hardwood identification," IAWA Bulletin New Series 10(3), 219-332. DOI: https://www.researchgate.net/publication/294088872

Zobel, B. J., and Sprague, J. R. (1998). "Predictions of mature and total tree wood properties from juvenile wood," in: Juvenile Wood in Forest Trees, Springer-Verlag, Berlin, Germany, pp. 173-187. DOI: 10.1007/978-3-642-72126-7_6 
Zobel, B. J., and van Buijtenen, J. P. (1989). "Variation within and among trees," in: Wood Variation: Its Causes and Control, Springer-Verlag, Berlin, Germany, pp. $72-$ 131. DOI: 10.1007/978-3-642-74069-5_3

Article submitted: January 22, 2021; Peer review completed: March 14, 2021; Revised version received and accepted: March 24, 2021; Published: March 26, 2021.

DOI: $10.15376 /$ biores.16.2.3563-3574 